\title{
Formulation of RTS health mix for menopausal women
}

\author{
Sonali Raut and Nalwade ViJaya
}

\begin{abstract}
The present study was undertaken to develop ready to serve (RTS) health mix for menopausal women. RTS health mix was prepared using functional foods such as, rajkeera seed, soybean, ragi, flax seed and oats.The RTS health mix was developed for menopausal women by using calcium rich foods like ragi, rajkeera seeds and isoflavone rich foods such as soybean and oats and phytoestrogen rich food, flaxseed. The acceptability of RTS health mix was studied by using five point ranking test (Ranganna et al., 1979). Nutrient content of highly accepted developed ready to eat health mix was analyzed by applying standard methods. Highly accepted health mix was stored in airtight polyethylene pouches, one at room temperature and another at refrigerator for two months and evaluated for its shelf -life. Overall acceptability of developed RTS health mix was ranging from 3.53 to 4.96 . Highly accepted developed RTS health mix contain good amount of protein $(16.7 \pm 0.35)$, calcium $(201.8 \pm 0.06)$ and isoflavone $28 \mathrm{mg}$. It was found that RTS health mix stored at refrigerator temperature for 60 days had low microbial count than that of stored at room temperature. Even after two months of storage RTS health mix found to have low microbial count therefore considered as microbial safe for consumption.
\end{abstract}

Key Words : Menopause, RTS health mix, Sensory evaluation, Nutrient analysis and shelf-life

How to cite this article : Raut, Sonali and Vijaya, Nalwade (2014). Formulation of RTS Health mix for menopausal women. Food Sci. Res. J., 5(2): 157-160.

NALWADE VIJAYA, Department of Foods and Nutrition, College of Home Science, Vasantrao Naik Marathwada Krishi Vidyapeeth, PARBHANI (M.S.) INDIA Email:vm_nalwade@rediffmail.com 